\title{
Theoretical Approximations Between Brazilian and Spanish Authors' Production in the Field of Knowledge Organization in the Production of Journals on Information Science in Brazil
}

\author{
Juliana Lazzarotto Freitas*, Rene Faustino Gabriel Junior***, \\ and Leilah Santiago Bufrem****
}
* / ***:Department of Information Science and Management, Paraná Federal University,
Av. Prefeito Lothário Meissner, 632, Jardim Botânico, Curitiba- Paraná- Brazil, **Information Science, São Paulo State University, UNESP, Marília, Brazil, $*<$ julianalf@ufpr.br>,**<rene@sisdoc.com.br>,***<santiagobufrem@gmail.com>
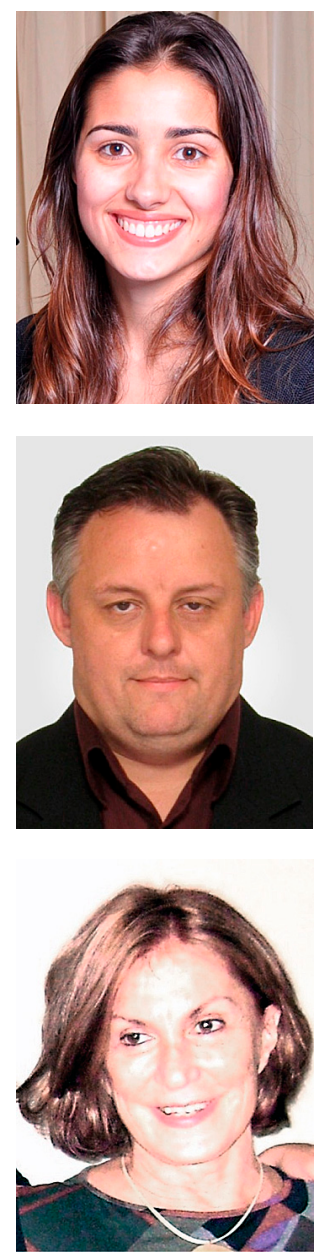

Freitas, Juliana Lazzarotto, Gabriel Junior, Rene Faustino, and Bufrem, Leilah Santiago. Theoretical Approximations Between Brazilian and Spanish Authors' Production in the Field of Knowledge Organization in the Production of Journals on Information Science in Brazil. Knowledge Organization. 39(3), 216-223. 11 references.

ABSTRACT: This work identifies and analyzes literature about knowledge organization (KO), expressed in scientific journals' communication of information science (IS). It performs an exploratory study on the Base de Dados Referencial de Artigos de Periódicos em Ciência da Informação (BRAPCI, Reference Database of Journal Articles on Information Science) between the years 2000 and 2010. The descriptors relating to "knowledge organization" are used in order to recover and analyze the corresponding articles and to identify descriptors and concepts which integrate the semantic universe related to KO. Through the analysis of content, based on metrical studies, this article gathers and interprets data relating to documents and authors. Through this, it demonstrates the development of this field and its research fronts according to the observed characteristics, as well as not- 
J. Freitas, R. Gabriel Junior, L. Bufrem. Theoretical Approximations Between Brazilian and Spanish Authors' Production

ing the transformation indicative in the production of knowledge. The work describes the influences of the Spanish researchers on Brazilian literature in the fields of knowledge and information organization. As a result, it presents the most cited and productive authors, the theoretical currents which support them, and the most significant relationships of the Spanish-Brazilian authors network. Based on the constant key-words analysis in the cited articles, the co-existence of the French conception current and the incipient Spanish influence in Brazil is observed. Through this, it contributes to the comprehension of the thematic range relating to KO, stimulating both criticism and self-criticism, debate and knowledge creation, based on studies that have been developed and institutionalized in academic contexts in Spain and Brazil.

Received 12 January 2012; Accepted 12 January 2012

\subsection{Introduction}

The concept of knowledge organization (KO) is currently connected to the dynamic context of a field whose concrete performance presents a pace of expansion and precise specifications, which is related to a pragmatic conjuncture, facilitating the representation and usage of acquired and organized knowledge. This concept comprises an area which seeks to establish theoretical bases (Gomes 2009), including the epistemological approaches with their implications for the elaboration of KO systems, which emphasize the role of classification.

Aiming to identify and analyze the relationships between the literature of Spain and Brazil, expressed in the discussions on $\mathrm{KO}$ in scientific journals, this study is focused on the articles present in the Base de Dados Referencial de Artigos de Periódicos em Ciência da Informação (BRAPCI, Reference Database of Journal Articles on Information Science) for the period of 2000-2010. The theoretical referential is based on Spanish authors.

Data about documents and authors were gathered and interpreted, and research fronts were identified, with the implicit intention of identifying the theoretical references between authors of $\mathrm{KO}$, leaving out the characteristics of their production. Thus, authorial relationships, as well as the theoretical currents which support them, can be visualized as well as the institutions to which such authors are linked, establishing the constituent relationships in the field of the Spanish-Brazilian network with its more significant influences. According to the studies that have been developed and institutionalized particularly in Spanish and Brazilian academic contexts, the comprehension of such a thematic range relating to the mentioned field favors criticism and self-criticism, stimulating debate and knowledge creation.

The basic presupposition is that the researchers of a field have the task of identifying, analyzing, and criticizing their own roles inside the area where they act, and, after having considered the results of the studies about this field, it is their task to regain commitment through creation, diffusion, and usage of knowledge. Although the meaning and control of knowledge might also be considered an expression of power, it is impossible to perform a critical project without the knowledge of this field.

This work highlights the importance of identifying the influence or epistemological fundaments on researchers, and, supported by the reflections of Guimarães and Sales (2010), the purpose of this study in favor of the reflection of the academic community about the field fundaments is reinforced. According to the authors, the conceptual dimension of knowledge organization is yet not solid, considering that "three distinct theoretic currents coexist, and not always in a very distinct form: subject cataloguing, indexation and documentary analysis." However, according to the authors, the documentary analysis current of French conception, has shown a fertile development in Brazil.

Nonetheless, it has been observed that, based on different theoretical referential and methodological perspectives, projects and studies between Brazil and Spain have been performed with the participation of institutional research groups, which especially focused on the current related to studies about information organization.

According to Guimarães and Sales (2010), the organization area relating to Information Science is responsible by the mediation between the production contexts and usage of information, particularly in regard to the analysis, description, and representation of the content of the documents-a process which is "most of the times named as Thematic Treatment of Information."

The most significant intellectual production in the field, even if initially performed through academic institutional means, has been registered in scientific journals, because its natural flow, after the stage of institutional validity by the peers, is directed to another 
consecrator evaluation, constituted by the editorial body in scientific journal production.

The scientific journal, as the most validated means for scientific communication since the $17^{\text {th }}$ century (Meadows 1999), is responsible for representing a large part of the knowledge developed by a science. Therefore, it constitutes a relevant registered contribution, guaranteeing input for research, study, and analysis in the consolidation of any science in a field of knowledge (Arboit, Bufrem, and Freitas 2010).

This study was supported by the use of the BRAPCI, which includes information on national journals of the IS field. BRAPCI is an important source of information to subsidize studies and proposals in the area of Brazilian scientific production in information science. For the construction of this referential database of Brazilian origin and development, printed and electronic journals' titles on information science were identified, and all the articles published since 1972 were retrieved and indexed. Being a database of referential and complete texts, it collects titles of journals on Information Science and their articles. It currently has thirty-four Brazilian journals about IS, with references, abstracts, and complete texts from 6,919 pieces published, printed or electronic. From the available journals, twenty-six are current and eight are considered historic (discontinued).

BRAPCI has been contributing to analytical and descriptive studies about editorial production of a developing area by supplying the students, professors, and researchers with a dynamic tool. It enlarges the documentary space available to teachers and provides them with the bigger picture on production in the field, while at the same time revealing the specifics of the scientific domain.

Domain Analysis (DA) currently comprises the main theoretical support in the field of information science with the intention of evaluating scientific productivity issues and identifying their theoretical relations. Birger Hjórland (2002), a pioneer in the application of this approach, in partnership with Hanne Albrechsten, supported its theory and methodology. In the perception of these researchers, the concept of domain has a rather polemic comprehension. It refers to a field of knowledge, activity, or interest in which certain knowledge is marked with defined limits and whose professionals or groups are entangled both in thought and in language, generating differentiated conceptions and interpretations. In order to facilitate the definition and delimitation of a domain area, Hjórland (2002) proposes eleven approaches to its identification, which can be combined in specific analyses or emphasized individually in studies.

The arguments of Lloyd also comprise a supporting part of the theoretical framework of this work. Lloyd's (1995) reflections in defense of the coherence between the theoretical and methodological aspects of an investigation do not dismiss the comprehension of the formation process of a domain of coherent scientific investigation. For the author, the validity of a scientific study depends on the articulation between empirical investigation and its theoretical methodological background. This way, it is possible to comprehend and expose the study object constituted by the researcher. This argument highlights the importance of scientific procedure as well as the relationships between the authors and the theoretical currents as elements articulated with this research, seeking to review the conceptual and methodological issues on the intellectual productions of IS researchers.

Based on this theoretical referential and the orientation towards a delimitated empiric corpus, the research tendencies in the field of information science can be identified, even more so when they are based on the usage of databases as sources of information for scientific production analyses. These databases facilitate the quick location and analysis of the information within them. Furthermore, being registered publications supported by peers and with editors as instances of legitimacy, they present larger consistency, generating credibility, precision, and reliability. Interpretation modes relating to production, to contemplated themes, and to the scientific institutional collaboration network can be established through the consideration of the mentioned aspects and based on the organization of the empiric material.

\subsection{Methodology}

The point of departure is an exploratory study in BRAPCI with the descriptive terms "knowledge organization," "treatment of information," "terminology," "documentary language," "documentary analysis," "indexation," "subject analysis," "knowledge representation," "thesaurus," "ontology," and "concept" in the key word field.

After procuring 235 articles signed by 120 authors, of diverse nationalities, between 2000 and 2010, it was possible to organize a database with the 5,977 references used by the authors to lay the foundation for their studies. In order to identify the cited authors of Spanish origin, all the references were analyzed, applying an identification criterion to the title in Span- 
ish, the place of publication, and, in uncertain cases, the recurrence of other sources of biographical nature. Ninety-four authors were identified with these characteristics; however, the analysis of their respective biographies resulted in the identification of twenty-nine authors of Spanish nationality.

Content analysis was adopted, supported by other metrical studies, to facilitate the clarification of the patterns of the information registered in the articles and the building of a frame of the most representative Brazilian authors in the corpus. With this frame, it was possible to identify the influences and existent relationships among them, recognizing the complexity of a scientific analysis of this nature.

Inside the BRAPCI system, a function was developed to correlate the Spanish authors and to identify those who cited them. Through this tool, the organization of the generated reports was made easier. Due to the inconsistency of some records, the analysis of such reports demanded a standardization effort, as the name of some authors is written in different forms, which raises difficulties in its identification process.

From the corpus of 120 different articles' authors, 63 were selected, with at least two articles about KO. This extraction enabled the creation of an Excel matrix, which relates the 29 authors of Spanish nationality referred to in the corpus of 235 BRAPCI articles with the 63 most productive citing authors. The data was dichotomized in a way so as to represent the citing and cited authors, and not the number of times they were cited. In this generation of data, the nineteen of the most productive authors who did not cite Spanish authors were identified, while two of those who were not cited by any of the most productive authors were eliminated from the spreadsheet. Using a $27 \times 44$ matrix, it was possible to export the data to Ucinet and proceed with the analysis of the relation between citing author and cited author.

The result of the matrix including citing and cited authors supported the construction of a second matrix. This time, the relation of co-citation was added with the purpose of identifying the theoretical currents of the authors and their relations in laying the foundations for the citing authors. A symmetrical matrix 27x27 was generated for this analysis.

\subsection{Data analysis}

The data showed that the author with largest impact on the theoretical foundations was Cabré, cited by nineteen authors, followed by García-Gutiérrez with thirteen citations. Gorcho, Moreiro González and
Curras were cited by ten authors. The significant presence of Cabré, representative Catalan author of the terminology field in European and IberoAmerican institutions and coordinator of a research group about the theme at Universitat Pompen Fabra, is possibly due to the influence of her work La terminologia: la teoria, els mètodes, les aplicacions, published in 1992, and subsequently translated into several languages. The majority of the articles adopt the main fundamentals of the author, to whom the terms are "specific cognitive units" of natural languages, and these, in turn, exist only in the interior of the "situation in which they are used." Thus, the terminology acquires a dynamic and pluralistic character as much it does from the perspective of shape or denomination as it does from the content, i.e., the idea. In this sense, specialized communication is singular, but diverse (Cabré 1992, \#), which reinforces the role of the scientific domain analyses based on studies about the relationships in which authors, themes, institutions, and geographic areas are covered.

Analyzing the most cited Spanish authors, it was observed that their formation derives from three distinct knowledge areas, from which the following categorization into three groups resulted: the most expressive, with 21 authors connected to knowledge organization $(\mathrm{KO})$; the second group, represented by three authors responsible for philosophical referential $(\mathrm{PH})$; and, lastly, a group of three representatives constituted by the authors whose focus is related to information technology (IT).

Observing Table 1, relating to most cited Spanish authors, one can note that, with the exception of Corcho, the most significant ones have a strong connection with Brazil. This is the case with Cabré, Currás, López Huerta, Moreiro González, García Quismondo, García Gutiérrez, and Fernández-Molina, who have all published articles in Brazilian journals on the field, some of them having researched in collaboration with Brazilian institutions. The Spanish authors most present in the citations of BRAPCI authors are from the Universidad Carlos III de Madrid.

Table 2 represents the influence of Spanish authors in the referential Brazilian frame, indicating the authors who cited them the most. Highlighted in this table: Guimarães, citing nine Spanish authors; Alvarenga e Sales, citing seven; Fujita and Rabello, who cite six; followed by other authors with five or less citations. Another highlight in this table is the presence of authors of other nationalities besides Brazilian, as is the case with Moreiro González e García Gutiérrez, from Spain, and Barité, from Uruguay. These authors, 


\begin{tabular}{|c|c|c|c|c|c|c|c|}
\hline Cited & $B R *$ & Citations & Field & Cited & $\mathrm{BR}^{*}$ & Citations & Field \\
\hline ALVITE DÍAZ, M. A. & - & 1 & $\mathrm{KO}$ & GARCIA MARCO, F. & - & 6 & $\mathrm{KO}$ \\
\hline CABRÉ, M. T. & Yes & 19 & $\mathrm{KO}$ & GOMEZ PEREZ, A. & - & 6 & IT \\
\hline CENTELLES, M. & - & 4 & $\mathrm{KO}$ & LOPEZ HUERTAS, M. & Yes & 3 & $\mathrm{KO}$ \\
\hline CODINA, L. & - & 8 & $\mathrm{KO}$ & LOPEZ YEPES, J. & - & 3 & $\mathrm{KO}$ \\
\hline CORCHO, O. & - & 10 & IT & MARTINEZ COMECHE, J. & - & 1 & $\mathrm{KO}$ \\
\hline CURRAS, E. & Yes & 10 & $\mathrm{KO}$ & $\begin{array}{l}\text { GARCÍA-QUISMONDO, M. Á. } \\
\text { M. }\end{array}$ & Yes & 2 & $\mathrm{KO}$ \\
\hline ESTEBAN NAVARRO, M. & - & 2 & $\mathrm{KO}$ & MOREIRO GONZÁLEZ, J. A. & Yes & 10 & $\mathrm{KO}$ \\
\hline FERNANDEZ LOPEZ, M. & - & 7 & IT & PEREZ GUTIERREZ, M. & - & 1 & $\mathrm{KO}$ \\
\hline FERNANDEZ MOLINA, J. & Yes & 8 & $\mathrm{KO}$ & RODRIGUEZ BRAVO, B. & - & 5 & $\mathrm{KO}$ \\
\hline FERRATER MORA, J. & - & 2 & $\mathrm{PH}$ & ROLDAN, I. & - & 1 & $\mathrm{PH}$ \\
\hline FRIAS, J. & - & 3 & $\mathrm{KO}$ & SAEZ VACAS, F. & - & 2 & $\mathrm{KO}$ \\
\hline GARCÍA GUTIERREZ, A. & Yes & 13 & $\mathrm{KO}$ & SAN SEGUNDO, R. M. & - & 1 & $\mathrm{KO}$ \\
\hline \multirow[t]{2}{*}{ GARCIA JIMENEZ, A. } & - & 4 & $\mathrm{KO}$ & SANCHEZ VAZQUEZ, A. & - & 2 & $\mathrm{PH}$ \\
\hline & & & & SANCHO, R. & - & 1 & $\mathrm{KO}$ \\
\hline
\end{tabular}

KO - Knowledge organization; IT - Information Technology; PH - Philosophy

* publication in Brazilian journals

Table 1. Spanish authors cited in the Brazilian journals of Information Science

Source: Authors (2011)

\begin{tabular}{|l|c|l|c|}
\hline Citing author & \multicolumn{1}{|c|}{$\begin{array}{c}\text { Quantity of } \\
\text { cited authors }\end{array}$} & Citing author & Quantity of cited authors \\
\hline GUIMARÃES, J. A. C. & 10 & LARA, M. L. G. & 4 \\
\hline ALVARENGA, L. & 7 & SILVA, D. L. & 4 \\
\hline SALES, R. & 7 & SOUZA, R. R. & 3 \\
\hline FUJITA, M. S. L. & 6 & ALMEIDA, M. B. & 3 \\
\hline RABELLO, R. & 6 & BARITÉ, M. & 3 \\
\hline KOBASHI, N. Y. & 5 & BONOTTO, M. E. K. K. & 3 \\
\hline MOREIRO-GONZÁLEZ, J. A. & 5 & CARDOSO, A. M. P. & 3 \\
\hline MOURA, M. A. & 5 & DZIEKANIAK, G. V. & 3 \\
\hline PINHO, F. A. & 5 & FERREIRA, G. I. S. & 3 \\
\hline PINTO, A. L. & 5 & GARCÍA GUTIÉRREZ, A. & 3 \\
\hline RODRÍGUEZ BARQUÍN, B. A. & 5 & VAN DER LAAN, R. H. & \\
\hline GOMES, H. E. & 4 & & \\
\hline
\end{tabular}

Table 2. Most productive authors and quantity of cited Spanish authors

Source: BRAPCI (2011)

although not Brazilians, were included in the study because the research considered publications made in Brazil, and not exclusively works published by Brazilian authors, even though these have been the more representative ones. The presence of researchers of other nationalities comes mainly from the results of scientific collaborations Brazilian researchers have conducted with researchers from such countries, through personal or institutional connections.
Graphic 1 was generated with the purpose of representing the relations of the citing authors (red circles) with the cited Spanish authors (square). Formations related to the thematic emphases appear as result of the analysis of the citing and cited. One of them, formed by the authors Smit, Galvão, Lima, Campos, and Café, whose referential is directly connected to the theories of Cabré, presents emphasis on terminology. The second standout group creates a 
J. Freitas, R. Gabriel Junior, L. Bufrem. Theoretical Approximations Between Brazilian and Spanish Authors' Production

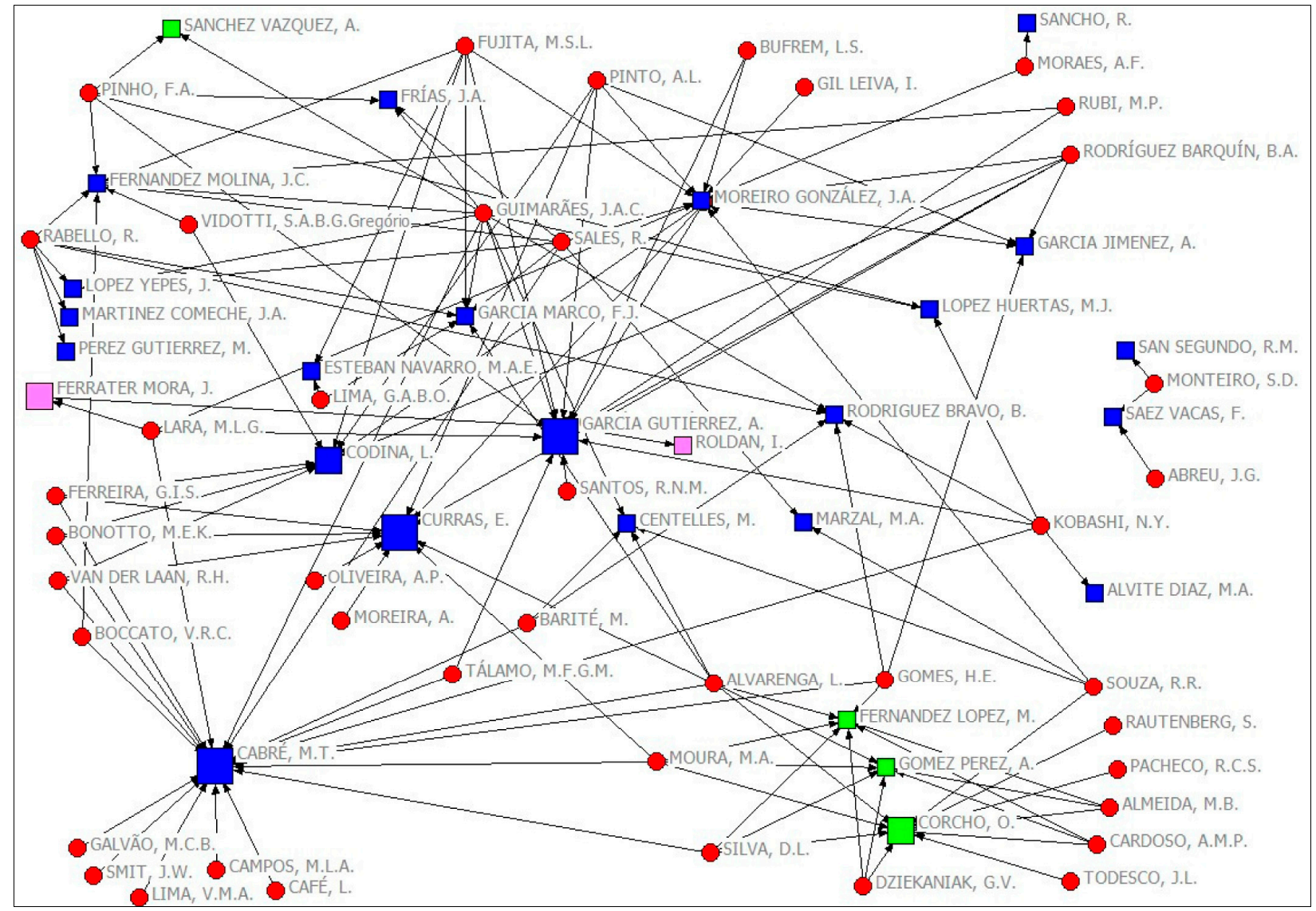

Figure 1. Citation network of Brazilian authors citing Spanish authors Source: Authors (2011)

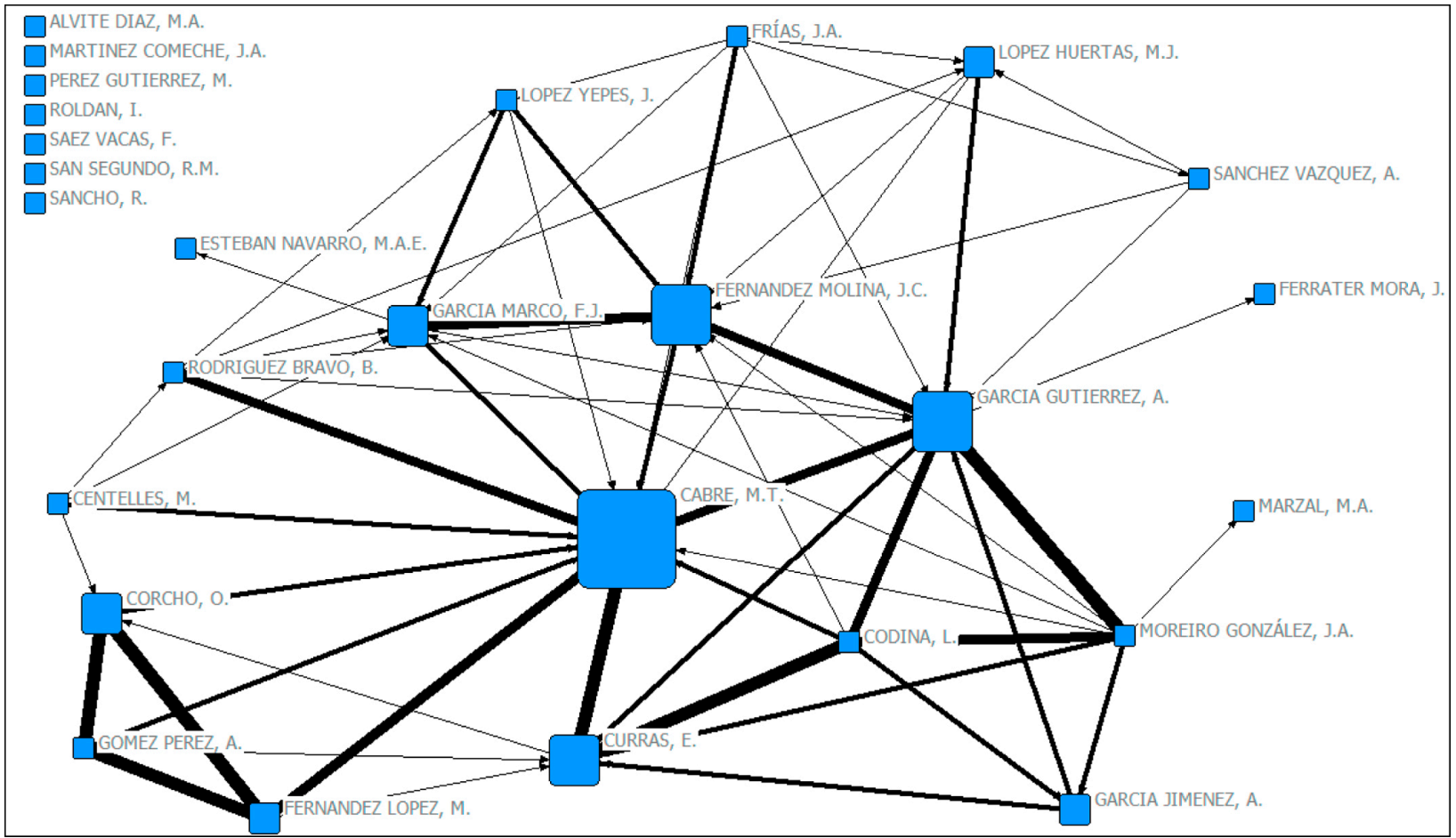

Graphic 1. Network of authors' co-citation Source: Authors (2011) 
dialogue between authors such as Currás and Codina, being constituted by Van Der Laan, Bonotto, and Ferreira.

The group with the largest technological emphasis is formed by Rautenberg, Pacheco, Almeira, Cardoso, Todesco, and Dziekaniak, who make a theoretical triangle with Fernandez Lopez, Gomez Perez, and Corcho. Researchers Moura, Silva, Gomes, and Alvarenga seek to relate these authors with Cabrés terminologies. As for the line of documentary analysis, a significant group of Spanish authors is formed with a wider and more diverse referential, highlighting the hegemonic influence of Moreiro González and García Gutierrez.

Through an outline of the traces which unite citing and cited, it is possible to identify and generate the Spanish authors' co-citation relationships, in an attempt to identify epistemological currents represented in them.

In order to generate the Spanish authors' cocitation relationship, the criterion used was that of being cited more than twice, excluding the 63 unitary relationships between co-citations, which allowed the creation of Graphic 1. This graphic notes the triad composed by Corcho, Gomez Perez, and Fernandes Lopez, all associated with the technology current and related to Cabré's theories. Another highlight is revealed in the triad which strongly relates authors Cabré, Curras, Garcia Gutierrez, Fernandez Molina, Garcia Marco, and Codina, constituting a big block of the KO fundament. Two other triads are perceivable, one of them being constituted by Monteiro González, Codina, and Garcia Gutierrez, and the other by Molina, Garcia Marco, and Lopez Yepes. In this representation, three dyads can also be located, the first formed by Rodriguez Bravo and Cabré, the second by Fernandez Molina and Frías, and the third by García Gutierrez and Lopez Huertas.

These relationships define the theoretical affinities between the Spanish authors, while also exhibiting a strong interconnection between technologies and terminology. This phenomenon, however, is insignificant in concerns to the documentation, the main author of which is Currás. A core of authors who support the researchers in $\mathrm{KO}$ can be observed, as well, co-existing with another group in the peripheral area, whose new ideas converge with the conception of the main core of Spanish authors or with the epistemological foci present in the central configuration.

These efforts reveal the structure of the objective relationships in which different authors, in diverse situations, assume positions in the field that can only be understood if "we are in conditions to refer to the position that one occupies in this field, if we know from where one is speaking" (Bourdieu 2004, 24). However, besides situating them institutionally and regionally, it is important to locate them in the semantic domain constituted by key words or descriptors attributed to them in order to know from where authors are speaking.

Analyzing the occurrence of constant key words in citing articles, the co-existence of the French conception current (Guimarães and Sales 2010) and the incipient Spanish influence in Brazil is noted through the visualization of the occurrence of key-words such as: knowledge organization (34), terminology (31), documentary language (25), knowledge representation (10), ontology (9), organization of information (9), linguistics (7), information recovery (6), theory of concept (5), and thesaurus (5). Considering the wide scope of the term knowledge organization as a descriptor of 34 works, the key word terminology appears as the most significant specific theme, being coherent with the presence of Cabré, the author with the largest impact on the theoretical fundaments of the works of the corpus.

This can be better understood when the Cabre's conception on the terminology is followed. She attests that, although it contradicts the perceptions which associate terminology only with standardization or normalization, it is able to represent the manifested diversity in the diverse subjects which compound it, and, in the distinct functions, they execute in the different conceptions of the discipline. In addition, the author points to the variety of practices offered by the discipline, of the users who use it, and who use the multiplicity of organizations approaching it. In the title La terminologia hoy: concepciones, tendencias y aplicaciones, Cabré (1995) seeks to synthesize only one subject: the terminology with the polyhedral perspective in its base, the regard to its fundaments or conceptions, to its foci or orientations, and its practices or applications.

Thus, in the majority of works, a profile is defined. This profile has begun to expand in Brazil with the creation of the Group Tema, which is a stimulating element in the relationships of co-existence between the French conception current and Spanish influence.

Another feature comes from the influence of Oscar Cocho, Gomez Perez, and Fernandez Lopez in the studies on ontologies, especially the ones related to the use of technologies in the organization of information. These studies present certain cohesion with the more recent reflections on the theme. 


\subsection{Conclusions}

The set of Brazilian authors who produced material about KO in the analyzed journals on IS with Spanish authors as their fundaments can still not be considered very significant. Only eleven authors are marked as citing five or more Spanish authors, from which only two published in cooperation with Spanish authors in Brazilian journals. Works exclusively by Spanish researchers with results published in Brazilian journals were also identified.

This scarcity tends to be surpassed by the indication that the relationship networks have become stronger. However, it does not rival the strong presence of the documentary analysis of French conception, according to the analysis of the most frequent key-words in citing articles.

The theoretical foundation of scientific works in the area reflects the nature of the exchange between researchers, favoring the reflection and study of $\mathrm{KO}$ currents of thought and meta-researches about intellectual production itself and the methodological configurations relating to the context of social and technological transformations of the surrounding context. Thus, the characteristic modes of thinking and doing research are reviewed, as well as the techniques, the instruments, the regime of production and management of knowledge, symbols, and the specific language which broadcast them. From this initial exploration, it is already possible to observe a tendency towards a theoretical proximity of Brazilian and Spanish authors in the area, marked by the citations and the thematic relationships which they represent.

While the application of the study to a concrete reality, as in this case here, limits the research to a specific relationship between researchers from two countries on the one hand, restricting the generalization of results, it also demonstrates modes of scientific production with comprehensive character, present in studies of different nature and regions, which can be explored in other situations, showing certain constancy and consistency between them.

Thus, movements related to the tendencies of studies presented in the period can be seen, as well as relationships between the authors, themes, institutions, and countries, which navigate in this area and certainly motivate other researchers of this type.

\section{References}

Arboit, Aline Elis, Bufrem, Leilah Santiago, and Freitas, Juliana Lazzaroto. 2010. Configuração epistemológica da Ciência da Informação na literatura periódica brasileira por meio de análise de citações (1972-2008). Perspectivas em ciência da informação 15n1: 18-43.

Brandt, Mariana, and Medeiros, Marisa Brascher Basílio. 2010. Folksonomia: esquema de representação do conhecimento? Transinformação 22: 111-21.

Bourdieu, Pierre. 2004. Os usos Sociais da ciência: por uma sociologia clínica do campo científico. São Paulo: Editora UNESP.

Cabré, Maria Teresa. 1992. La terminologia: la teoria, les mètodes, les aplications. Barcelona: Les Naus d'Empúries.

Cabré, Maria Teresa. 1995. La terminología hoy: concepciones, tendências y aplicaciones. Ciência da informação $24 \mathrm{n} 3$.

Cabré, Maria Teresa. 1999. La terminología: representación y comunicación: elementos para una teoría de base comunicativa y otros artículos. Barcelona: Universitat Pompeu Fabra.

Gomes, Hagar Espanha. 2009. Tendências da pesquisa em organização do conhecimento. Tendências da pesquisa brasileira em ciência da informação 2: 60-88.

Guimarães, José Augusto Chaves, and Sales, Rodrigo de. 2010. Análise documental: concepções do universo acadêmico brasileiro em ciência da informação. DataGramaZero 11n1. Available: http://www. dgz.org.br/fev10/Art_02.htm. English translations are by the authors of the present article.

Hjørland, Birger. 2002. Domain analysis in information science: eleven approaches - traditional as well as innovative. Journal of documentation 58: 422-62.

Lloyd, Christopher. 1995. As estruturas da história. Rio de Janeiro: Jorge Zahar.

Meadows, Arthur Jack. 1999. A comunicação científica. Brasília: Briquet de Lemos.

Vogel, Michely Jabala Mamede. 2007. A evolução do conceito de linguagem documentária: as linha francesa e brasileira. In ENANCIB - Encontro $\mathrm{Na}$ cional de Pesquisa em Ciência da Informação, 2007, Salvador. Anais do VIII ENANCIB. Salvador: ENANCIB, v. 8. p. 1-14. 